Agro-Science Journal of Tropical Agriculture, Food, Environment and Extension Volume 20 Number 3 (July 2021) pp. 30 - 36

ISSN 1119-7455

\title{
PRODUCTION AND EVALUATION OF BREAKFAST MEAL USING BLENDS OF SORGHUM, BAMBARA NUT AND DATE PALM FRUIT FLOUR
}

\author{
${ }^{* 1}$ Olurin T.O., ${ }^{2}$ Abbo E.S. and ${ }^{1}$ Oladiboye O.F. \\ ${ }^{1}$ Department of Chemical and Food Sciences, Bells University of Technology, Ota, Nigeria \\ ${ }^{2}$ Department of Food Technology, Kaduna Polytechnic, Kaduna State, Nigeria \\ *Corresponding author email: toolurin@bellsuniversity.edu.ng, tayeolurin@gmail.com
}

\begin{abstract}
Breakfast meals are described as any food obtained with or without supplementation through swelling, roasting, grinding, rolling, or flaking of any cereal. This study is aimed to produce and evaluate the functional, pasting, proximate composition and sensory properties of a breakfast meal made from blends of sorghum, bambara and date flours. Gruels were made using composite flour $(450 \mu \mathrm{m})$ in ratio of 80:15:5, 70:20:10, 60:25:5 and 100:0:0 for sorghum, bambara and date palm respectively. Samples were assessed for functional, pasting, proximate and sensory properties using standard procedures. Data were analyzed using ANOVA at $p=0.05$. The functional properties of the flour blends were significantly $(p=0.05)$ affected by the increasing level of supplementation of bambara and date palm flour. There was a decrease in gelatinization temperature and viscosity as the level of supplementation of bambara nut and date palm flours increased. The gruel from 100\% sorghum flour (control) had the highest pasting properties. Proximate composition of the gruels was as follows: moisture, 10.79-9.22\%; crude protein, 4.50-10.37\%; crude fat, 1.56-2.12\%; ash, 2.86-1.76\%; crude fibre, 0.10-0.88\% and carbohydrate, 80.33-75.15\%. Samples made from 60:25:15 flour blends showed significantly $(p=0.05$ ) highest sensory qualities while gruel from 100\% sorghum was lowest. The use of bambara nut and date palm fruits at various substitution levels in the formulation of sorghum breakfast gruel significantly $(p=0.05)$ enhanced their quality characteristics.
\end{abstract}

Key words: bambara nut, breakfast meal, composite flour, date palm

\section{INTRODUCTION}

Cereal grains have great potentials as domestic and industrial raw materials in the production of a variety of food products because of their functional and nutritional characteristics. However, their uses have been limited to only household preparation of local dishes in most instances. Their ability could be highlighted by the technical processing of under-utilized cereals into industrial or consumer goods. While cereal grains, due to their low cost, provide the bulk of the energy requirement in local meals, they are also surplus in the essential amino acids, methionine and cystine containing sulphur, but weak in lysine Kanu et al. (2009). Relative to lysine and sulphur amino acid contents, legume and cereal proteins are nutritionally complementary, depending on the contents of the second limiting amino acids especially threonine in cereals and tryptophan in legumes (Duranti, 2006), hence the need to blend legumes with cereals in the development of food products (Okafor and Usman, 2015). Compared to animal protein, the comparatively lower cost of vegetable protein and the preference of certain individuals for plant-based protein over that of animal sources have contributed to this growing industrial demand for legume proteins (Arogundade et al., 2011).
Bambara groundnut is a popular crop in subSaharan Africa, where the crop is most prominent in the local dishes of rural communities. Nigeria has been identified as one of the centres of origin for Bambara nuts and as the largest crop producer in Africa. Nigeria produces about one third (100,000 metric tons) of Africa's total production of 310,000 metric tons per year (Hillocks et al., 2012). The crop is believed to have originated between Jos and Yola in the Northeastern Nigeria region. Currently, the crop is grown throughout the country, except for the riverine and swampy areas. The colour of the seed coat, seed sizes, eye pigmentation, pod shape, growth habitat, and other crop characteristics are widely varied across the nation (Aviara et al., 2013). It can be said that the crop now widely cultivated and consumed in the semi-arid regions of sub-Saharan Africa is the third largest food legume in those regions after cowpeas and groundnuts (Mkandawire, 2007). It has been considered a balanced food and is highly nutritious. Its seed contains $49.0-63.5 \%$ starch, $15-25 \%$ protein, $4.5-7.4 \%$ fat, $5.2-6.4 \%$ fibre, $3.2-4.4 \%$ ash and $2 \%$ mineral compared to whole fresh cow milk $88 \%$ moisture, $4.8 \%$ starch, $3.2 \%$ proteins, $3.4 \%$ fat, $0.7 \%$ ash and $0.01 \%$ cholesterol. Its chemistry differs from that of soybean (Mkandawire, 2007). 
Date fruit known as dabino in Hausa and tamr in Arabic is a palm plant belonging to the family Arecaceae. The tree is commonly found in the Canary Island, Northern Africa, Arabia and South West of Asia to Pakistan and India. It is cultivated for its sweet bearing fruits and as such, is considered to be the most important tree in most of the Arabian countries (Mustafa et al., 1993). Date fruits are considered a complete diet and a very important item of food. With plenty of vitamins and minerals, dates have $25 \%$ more potassium than bananas while being free from fat, sodium and cholesterol. Dates play an important role in the diet and treatment of obesity and are the most important sources of energy and food in date producing and non-date producing areas (Foroogh, 2009). In Nigeria, particularly in the northern part, dates have become a major source of nutrition and energy source among Muslims and even the non-Muslim community. For Muslims, it is a customary religious meal for breaking day-long fast during the holy month of Ramadan (Ahmad et al., 2013).

Any food obtained by swelling, roasting, grinding, rolling or flaking of any cereal is known as breakfast cereal. It is a pre-cooked or ready-toeat grain food typically consumed with milk or cream for breakfast in the United States or elsewhere, often consumed with sugar, syrup, or fruit (Usman et al., 2015). It is vital for our body and mind to eat breakfast because the brain and muscles would be short of caloric energy to work after 8-12 h without food. The typical Nigerian diet contains foods that are mainly focused on carbohydrates. There is, therefore, the need for strategic use of inexpensive sources of high protein that complement the staple diet's amino acid profile to increase nutritional value. Protein deficiency has become a dietary issue facing the world, particularly in underdeveloped and developing countries (Enweremadu et al., 2008). In developing countries such as Nigeria, animal protein is costly; hence, it is important to find an alternative way to compensate for low protein availability and also to improve vitamins and minerals in the staple foods.

In order to improve the nutritional quality of these cereal foods, this research aimed to produce and evaluate breakfast meals made from composite flour of cereals, legumes, by strengthening them with cheap plant sources such as bambara nut, as animal protein sources are too costly for the average Nigerian. Date fruit has also been added to act as a nutritious and safe source of dietary fiber. In the production of novel food products, the development of breakfast cereals from blends of local sorghum, bambara nut and date fruit is useful. The aim of this research was therefore to produce and evaluate breakfast meals made from blends of sorghum, bambara nut and date palm flours.

\section{MATERIALS AND METHODS}

Preparation of Sample

Five kilograms each of sorghum (Sorghum bicolor), cream coloured bambara nut (Vigna subterranean (L.) Verdc) and dry date fruits (Phoenix dactylifera L.) were purchased from a local market Sango-Ota, Ogun State of Nigeria and were processed into their individual flours using the method of Nnam (2001). The breakfast cereal was produced using the modified Okafor and Usman's (2014) method, shown in Table 1.

\section{Determination of Functional Properties of Composite Flour}

The determination of the functional properties of the composite flour used for the production of breakfast meal is described as follows: bulk density was determined using the method of Akinsola et al. (2018). Five grams flour sample was put into a 100 $\mathrm{ml}$ measuring cylinder. The cylinder was tapped continuously until a constant volume was obtained. The weight of flour ( $\mathrm{g}$ ) divided by its volume (ml) gave the bulk density. Water absorption capacity of the flour samples was determined using the method by Beuchat (1977). In a 15-ml centrifuge tube, $1 \mathrm{~g}$ of the sample was weighed, and $10 \mathrm{ml}$ of water was added to it. The suspension was then stirred for 5 min. using a magnetic stirrer and centrifuged for 30 min. at 3,500 rpm. Using a $10 \mathrm{ml}$ measuring cylinder, the collected supernatant was weighed. The difference between the initial water applied to the sample and the volume of the supernatant obtained after centrifugation was measured as the absorbed water.

In a $15 \mathrm{ml}$ centrifuge tube, $1 \mathrm{~g}$ of the sample was weighed, and $10 \mathrm{ml}$ of soybean oil was applied to it. The suspension was then stirred for $5 \mathrm{~min}$. using a magnetic stirrer and centrifuged for $30 \mathrm{~min}$. at 3,500 rpm. Using a $10 \mathrm{ml}$ measuring cylinder, the collected supernatant was weighed. The difference between the initial oil applied to the sample and the volume of the supernatant collected after centrifugation was measured as the absorbed oil. Swelling power of the composite flour was determined using the modified method of Yuliana et al. (2018). One gram of the sample was weighed and transferred into clean dry tubes and re-weighed ( $\mathrm{W}_{1}$ in $\left.\mathrm{g}\right)$. The sample was dispersed in $10 \mathrm{ml}$ distilled water using a magnetic stirrer. The resulting slurry was heated in a water bath at a temperature of $85^{\circ} \mathrm{C}$ for $30 \mathrm{~min}$. The mixture was cooled to room temperature. It was centrifuged at $2,500 \mathrm{rpm}$ for $15 \mathrm{~min}$. to separate the gel and the supernatant. The swollen sediment was then weighed $\left(\mathrm{W}_{2}\right.$ in $\mathrm{g}$ ) and the difference in weight recorded as the swelling capacity.

Table 1: Formulation of composite flour

\begin{tabular}{lccc}
\hline Sample & Sorghum (\%) & Bambara nut (\%) & Date (\%) \\
\hline SF (control) & 100 & 0 & 0 \\
SBGF1 & 80 & 15 & 5 \\
SBGF3 & 70 & 20 & 10 \\
SBGF5 & 60 & 25 & 15 \\
\hline
\end{tabular}

$\mathrm{SF}$ is sorghum flour, SBGF1 is $80 \%$ sorghum $+15 \%$ bambara nut flour $+5 \%$ date fruit flour, SBGF3 is $80 \%$ sorghum $+20 \%$ bambara nut flour $+10 \%$ date fruit flour, SBGF5 is $60 \%$ sorghum $+25 \%$ bambara nut flour $+15 \%$ date fruit flour 


\section{Determination of Pasting Properties of the Composite Flour}

The modified method of Ojo et al. (2017) was adopted to determine the pasting properties of the composite flours using a Rapid Visco Analyzer. A sample of the composite flour (2.5 g) was weighed into a previously dried canister and $25 \mathrm{ml}$ of distilled water was dispensed into the canister containing the sample. The suspension was thoroughly mixed and the canister was fitted into the Rapid Visco Analyzer as recommended. Each suspension was kept at $50^{\circ} \mathrm{C}$ for $1 \mathrm{~min}$. and then heated up to $95^{\circ} \mathrm{C}$ with a holding time of $2 \mathrm{~min}$. followed by cooling to $50^{\circ} \mathrm{C}$ with $2 \mathrm{~min}$. holding time. The rate of heating and cooling were at a constant rate of $11.85^{\circ} \mathrm{C}$ per minute. Peak viscosity, trough, breakdown, final viscosity, set back, are read from the pasting profile with the aid of thermocline for windows software connected to a computer. A measure of $25.0 \pm 0.1 \mathrm{ml}$ of distilled water (corrected to compensate for the sample's 14\% base correction) was introduced into the new bottle. $X \pm 0.01 \mathrm{~g}$ (14\% moisture base) of the sample was weighed into a weighing vessel and the sample was transferred to the water surface. The quantity of material used $(X)$ depends on the type of material.

\section{Determination of Proximate Composition of Breakfast Meal}

The moisture content, total ash, crude protein, crude fiber, and crude fat of the composite flours were determined using AOAC (2000) Official Methods 925.09, 923.03, 979.09, 962.09, and 4.5.01, respectively.

\section{Statistical Analysis}

The data were analyzed using SPSS software application (version 21.0). The mean and standard deviations were used to present the data. The determinations have been made in triplicate. The mean value of the data was subjected to analysis of variance (ANOVA) to determine the level of significant $(p=0.05)$ differences.

\section{RESULT AND DISCUSSION \\ Functional Properties of Sorghum Based Breakfast Meal}

Omueti et al. (2009) described the significance of functional properties of food materials as the pointer to the ease of use of the material. Bulk density is a good indicator in the selection of appropriate packaging materials and quantity of the powdery food (Ijarotimi and Keshinro, 2013).

Table 2 shows the functional properties of the breakfast meal flour blends. The bulk density of the breakfast meal flour ranged from 1.0021 in the SF sample to $1.0016 \mathrm{~g} \mathrm{dl}^{-1}$ in the SBGF5 sample. This indicates that all samples had low bulk densities. Results further showed that significant difference $(p=0.05)$ in water absorption capacity (WAC) in the samples with sample SF having the highest

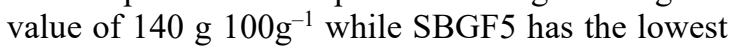

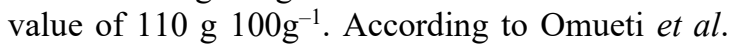
(2009), WAC is the ability of a product to associate with water under a condition where water is limiting. Therefore, the difference between the samples in WAC can therefore be due to their respective hydrophilic component materials, such as carbohydrates that bind more water than either protein or lipid (Mbaeyi, 2005). The WAC reduced with an increasing proportion of bambara nut and date palm flour addition to the breakfast cereal. This was an indication that the WAC of the composite flours was affected by the level of substitution. The findings of this study were in agreement with the result obtained by Mbata et al. (2009) when substituting ogi with bambara groundnut flour, whereby the WAC values of a blend of bambara nut flour to ogi decreased with an increase in bambara nut concentration.

The oil absorption capacity (OAC) values

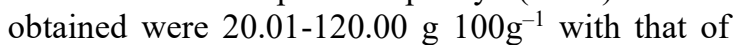
SBGF5 being the highest. Contrary to WAC behaviour of the breakfast cereal, the oil absorption capacity (OAC) of the sample increased with an increasing proportion of bambara nut and date palm

Table 2: Functional properties of sorghum-based breakfast meal flour

\begin{tabular}{|c|c|c|c|c|}
\hline Sample & $\begin{array}{c}\text { Bulk density } \\
\left(\mathrm{g} \mathrm{dl}^{-1}\right)\end{array}$ & $\begin{array}{l}\text { Water absorption capacity } \\
\left({\left.\mathrm{g} 100 \mathrm{~g}^{-1}\right)}\right.\end{array}$ & $\begin{array}{l}\text { Oil absorption capacity } \\
\left({\left.\mathrm{g} 100 \mathrm{~g}^{-1}\right)}\right.\end{array}$ & $\begin{array}{c}\text { Swelling capacity } \\
(\%)\end{array}$ \\
\hline SF (control) & $1.0021 \pm 0.00^{\mathrm{a}}$ & $140.01 \pm 0.01^{\mathrm{a}}$ & $20.01 \pm 0.01^{\mathrm{d}}$ & $4.57 \pm 0.01^{\mathrm{b}}$ \\
\hline SBGF1 & $1.0019 \pm 0.00^{\mathrm{a}}$ & $120.00 \pm 0.01^{\mathrm{b}}$ & $80.00 \pm 0.01^{\mathrm{c}}$ & $4.62 \pm 0.01^{\mathrm{b}}$ \\
\hline SBGF3 & $1.0016 \pm 0.00^{\mathrm{a}}$ & $120.00 \pm 0.01^{\mathrm{b}}$ & $100.00 \pm 0.00^{\mathrm{b}}$ & $5.04 \pm 0.01^{\mathrm{ab}}$ \\
\hline SBGF5 & $1.0016 \pm 0.00^{\mathrm{a}}$ & $110.00 \pm 0.01^{\mathrm{c}}$ & $120.00 \pm 0.01^{\mathrm{a}}$ & $5.56 \pm 0.01^{\mathrm{a}}$ \\
\hline
\end{tabular}

abcd represents significantly $(p=0.05)$ different means on the same column,

SF is sorghum flour, SBGF1 is $80 \%$ sorghum $+15 \%$ bambara nut flour $+5 \%$ date fruit flour,

SBGF3 is $80 \%$ sorghum $+20 \%$ bambara nut flour $+10 \%$ date fruit flour, SBGF5 is $60 \%$ sorghum $+25 \%$ bambara nut flour $+15 \%$ date fruit flour

Table 3: Pasting properties of sorghum-based breakfast meal flour

\begin{tabular}{|c|c|c|c|c|}
\hline Parameters & Control & SBGF1 & SBGF3 & SBGF5 \\
\hline Peak viscosity (RVU) & $816.00 \pm 0.02^{\mathrm{a}}$ & $642.00 \pm 0.03^{b}$ & $577.00 \pm 0.02^{\mathrm{c}}$ & $540.00 \pm 0.03^{c}$ \\
\hline Trough (RVU) & $695.00 \pm 0.07^{\mathrm{bc}}$ & $548.00 \pm 0.09^{\mathrm{a}}$ & $515.00 \pm 0.02^{\mathrm{b}}$ & $501.00 \pm 0.09^{c}$ \\
\hline Breakdown (RVU) & $25.00 \pm 0.07^{\mathrm{c}}$ & $76.00 \pm 0.04^{\mathrm{b}}$ & $76.00 \pm 0.01^{\mathrm{b}}$ & $121.00 \pm 0.08^{\mathrm{a}}$ \\
\hline Final viscosity (RVU) & $2361.00 \pm 0.02^{\mathrm{c}}$ & $1689.00 \pm 0.00^{\mathrm{a}}$ & $1549.00 \pm 0.01^{\mathrm{b}}$ & $1436.00 \pm 0.02^{\mathrm{b}}$ \\
\hline Setback (RVU) & $1666.00 \pm 0.04^{\mathrm{d}}$ & $1174.00 \pm 0.04^{\mathrm{c}}$ & $1001.00 \pm 0.02^{\mathrm{b}}$ & $935.00 \pm 0.00^{\mathrm{a}}$ \\
\hline Peak time (min) & $7.00 \pm 0.02^{\mathrm{a}}$ & $5.13 \pm 0.06^{\mathrm{b}}$ & $5.13 \pm 0.01^{\mathrm{b}}$ & $5.07 \pm 0.03^{\mathrm{bc}}$ \\
\hline Pasting temperature $\left({ }^{\circ} \mathrm{C}\right)$ & $89.60 \pm 0.01^{\mathrm{a}}$ & $86.35 \pm 0.02^{\mathrm{ab}}$ & $85.60 \pm 0.00^{\mathrm{b}}$ & $85.50 \pm 0.03^{b}$ \\
\hline
\end{tabular}

RVU is "Rapid-Visco Analyser Units". Other notations and abbreviations as explained in Table 2 
inclusion to the blended breakfast cereals. The higher $\mathrm{OAC}$ exhibited by higher percentage bambara nut and date palm addition may be attributed to high protein content and low water absorption of the composite flour. Lipid retention is an index of the ability of the protein to absorb and retain oil/water. High OAC of food materials improve mouthfeel and flavour retention (Adepeju et al., 2014). The swelling capacity of the samples

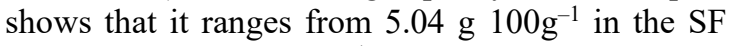

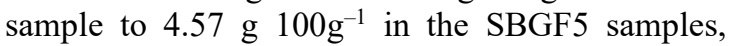
there was no significant $(p=0.05)$ difference between the samples. The swelling capacity increased with the increasing percentage of bambara nut and date palm addition in the breakfast blend. The flour blend with $60 \%$ sorghum, 25\% bambara groundnut and 15\% date palm fruit (SBGF5) had the highest swelling capacity while SF had the least. Generally speaking, swelling capacity actually measures the firmness of the bonds in the crystalline part of the starch granule which ultimately demonstrated easiness of cooking the starch or flour. Usually, the starch granules with more crystalline areas and stronger bonds swell less in cold or hot water as it forms a low viscosity paste with higher retrogradation (Govindasamy et al., 1996).

\section{Pasting Properties of the Sorghum Based Breakfast Meal}

Pasting characteristic is important in predicting the behaviour of food paste during and after cooking. Attainment of the pasting temperature is essential in ensuring swelling, gelatinization and subsequent gel formulation during processing (Akinsola et al., 2018). The pasting properties of flours from different blends of sorghum/bambara nut/date palm are shown in Table 3. The pasting properties of flours from different blends of sorghum/bambara nut/date palm for production of breakfast meal differ significantly $(p=0.05)$. The pasting properties for peak viscosity, trough, breakdown, final viscosity setback peak time and pasting temperature were within the ranges of 540-816, 501-696, 25-21, 1,436-2,361, 935-1,666 Rapid-Visco Analyser Units (RVU), 5.07-7.0 min. and 85.5-89. $6^{\circ} \mathrm{C}$, respectively. Sandhu et al. (2007) reported peak viscosity of starchy food during cooking $\left(50-90^{\circ} \mathrm{C}\right.$ reflects the capacity of the starch to absorb water and swell). In this study, SF (control) sample had the highest peak viscosity (816 RVU), trough viscosity (695 RVU), final viscosity (2,361 RVU) and setback (1,666 RVU).

In this study, SF (control) sample has the highest peak viscosity (816 RVU), trough viscosity (695 RVU), final viscosity (2,361 RVU) and setback (1,666 RVU). Peak viscosity is suggestive of the strength of pastes which are formed from gelatinization during processing in food applications which could be as a result of amylase activity in the flour blends which resulted in the changes in viscosity of the flours (Akinsola et al., 2018). The lowest breakdown was shown by SF (control), while SBGF5 showed the highest breakdown. Its high thermal stability was shown by the smallest breakdown of SF flour. The lowest final viscosity of 1,436 RVU was shown by SBGF5. Similarly, the lowest setback of 935 RVU was shown by SBGF5, suggesting its lower propensity to exhibit retrogradation. Because of the $25 \%$ blend of bambara nut and $15 \%$ date palm inclusion in the blend, this phenomenon may be due to higher protein content. The lowest pasting temperatures of $85.5^{\circ} \mathrm{C}$ were shown by SBGF5. The pasting temperature indicates the minimum temperature needed for gelatinization, as well as the temperature at which the viscosity during the heating phase begins to increase. The granules begin to swell when the temperature is higher than that at which gelatinization occurs (Sanni et al., 2004; Ikegwu et al., 2010). There was also a significant $(p=0.05)$ difference in the peak time of the SF and blended composite flour samples; the control sample (SF) had the highest value of 7.0 while sample SBGF5 had the lowest value of 5.13.

\section{Proximate Composition of Sorghum Based Breakfast Meal}

The proximate analysis of the control and sorghumbased breakfast cereal are presented in Table 4. Results showed that the higher the substitution level the lower the moisture content of the sorghumbased meal. Sample SF had significantly $(p=0.05)$ highest amounts of moisture content (10.75) while sample SBGF5 has significantly $(p=0.05)$ lowest moisture contents (9.22\%). Kabuo et al. (2015) noted that different food materials have different capacity for absorbing or retaining moisture which may exist as absorbed water. The relatively high amount of moisture in the $100 \%$ sorghum-based breakfast gruel could be a disadvantage, as high moisture content of foods has been implicated in their lower shelf life due to microbial attack (Adeyeye and Ayejuyo, 1994; Kabuo et al., 2015).

The protein content of the sorghum flour ranges from $4.05 \%$ in the control sample (SF) to $10.37 \%$ in the SBGF5 sample. It was observed that the protein content of sorghum-based breakfast gruel increased significantly $(p=0.05)$ with increasing bambara nut ratio of the gruel blend. Thus, the SBGF5 sample had significantly $(p=0.05)$ the highest amount of protein. This agrees with Ijarotimi and Keshinro (2013) who worked on the nutrient composition and protein quality of potential complementary foods formulated from the combination of fermented popcorn, African locust and bambara nut flour. Eneche (2006) reported a similar increase in the protein content of bakery products when African yam bean flour was added. The carbohydrate content of the breakfast gruel ranged from $80.33 \%$ in the SF sample to $75.15 \%$ in the SBGF5 sample. There was a significant $(p=0.05)$ difference in the 
carbohydrate content of the sorghum based cereal gruel as the level of substitution increased which was in agreement with results obtained by Okoye and Obi (2017). The ash content of the sorghum based cereal ranges from $2.86 \%$ in the SF sample to $1.76 \%$ in the SBGF5. The ash content reduced with increasing bambara nut substitution in the gruel formulation. This showed that the addition of bambara nut and date palm flour significantly ( $p=$ 0.05 ) affected the ash content of the breakfast gruel. The crude fibre content of the gruel was between $0.12-0.88 \%$. It was also observed that the crude fibre content of the sorghum-based gruel increased significantly $(p=0.05)$ when compared with the gruel from $100 \%$ sorghum flour. Crude fibre provides beneficial physiological effect to the human body, stimulates and accelerates intestinal contraction, adds to faecal volume, aids digestion and prevents cancer (Lattimer and Haub, 2010). The ash content of the gruel made from $100 \%$ sorghum flour (control) was significantly $(p=0.05)$ higher when compared to those made from composite flour. The ash content of food is an indication of the number of minerals in the diet (Okpala et al., 2013). The fat content of the samples ranges from $1.56 \%$ in the control sample (SF) to $2.12 \%$ in the SBGF5 sample. There is a proportionate increase in the fat content of the breakfast gruel as the percentage addition of bambara nut and date flour increases. A similar trend was observed by Ijarotimi and Keshinro (2013), Okoye and Obi (2017) and Sodipo et al. (2018).

\section{Sensory Properties of Sorghum-Based Breakfast Cereal}

The sensory properties of the gruel made from the composite flours in terms of colour, taste, aroma, consistency and overall acceptability are presented in Table 5. The mean scores of sensory attributes were 5.85-6.50, 5.00-6.95, 5.00-6.55, 5.70-6.80 and
5.30-6.95 for colour, taste, flavour, consistency and overall-acceptability, respectively. Colour is an important parameter in assessing quality of food materials; it is also a pointer to adequacy of formulation (Ogundele et al., 2015). The colour score of the blended sorghum meal ranged from 5.85-6.50. The highest colour score of 6.50 was observed for SBGF1. However, it was not significantly $(p=0.05)$ different from that of SBGF3 and SBGF5 of 6.40 . The flour with $100 \%$ Sorghum (SF) recorded the least score of 5.85 .

Similarly, taste is the sensation of flavour perceived in the mouth and throat on contact with a substance and it is one of the most important attributes watched out for in a food product. Taste could be affected by the types and quality of ingredients and could also depend on the formulation of the food material (Small and Prescott, 2005). Means of taste scores range between 5.00 and 6.95 . The flour blend with $60 \%$ sorghum, $25 \%$ bambara nut and $15 \%$ date palm fruit (SBGF5) recorded the highest score (6.95) while SF (control) had the lowest score of 5.00. This could be attributed to the percentage addition of bambara nut and date palm to the blended breakfast cereal. Aroma is a distinctive, typical pleasant smell perceived by the olfactory sense (Small and Prescott, 2005). The mean scores for aroma of the blended sorghum-based breakfast gruel ranged from 5.00-6.55 on a nine-point hedonic scale. The flour blend with $60 \%$ sorghum, $25 \%$ bambara nut and $15 \%$ date palm fruit (SBGF5) recorded the highest flavour score of 6.55 while SF had the least score of 5.85 for flavour. Consistency score range was 5.70-6.80. The highest score (6.80) was that recorded for SBGF5 while SF (control) had the lowest score of 5.70. Overall acceptability refers to the general acceptance of the product with reference to all the discriminating sensory attributes of the sample (Ogundele et al., 2015).

Table 4: Proximate composition of sorghum-based breakfast meal flour

\begin{tabular}{|c|c|c|c|c|}
\hline Parameters $(\%)$ & SF & SBGF1 & SBGF3 & SBGF5 \\
\hline Crude protein & $4.50 \pm 0.01^{\mathrm{d}}$ & $5.98 \pm 0.01^{\mathrm{c}}$ & $6.11 \pm 0.00^{\mathrm{b}}$ & $10.37 \pm 0.01^{\mathrm{a}}$ \\
\hline Carbohydrate & $80.33 \pm 0.01^{\mathrm{a}}$ & $80.16 \pm 0.01^{b}$ & $79.62 \pm 0.01^{\mathrm{c}}$ & $75.15 \pm 0.01^{\mathrm{d}}$ \\
\hline Ash & $2.86 \pm 0.01^{\mathrm{a}}$ & $2.32 \pm 0.01^{\mathrm{b}}$ & $2.11 \pm 0.01^{\mathrm{c}}$ & $1.76 \pm 0.01^{\mathrm{d}}$ \\
\hline Crude fiber & $0.12 \pm 0.01^{\mathrm{d}}$ & $0.67 \pm 0.01^{\mathrm{b}}$ & $0.81 \pm 0.01^{\mathrm{c}}$ & $0.88 \pm 0.01^{\mathrm{a}}$ \\
\hline Moisture & $10.79 \pm 0.01^{\mathrm{a}}$ & $9.35 \pm 0.01^{\mathrm{b}}$ & $9.26 \pm 0.01^{\mathrm{c}}$ & $9.22 \pm 0.01^{\mathrm{d}}$ \\
\hline Fat & $1.56 \pm 0.01^{\mathrm{d}}$ & $1.87 \pm 0.01^{\mathrm{c}}$ & $2.04 \pm 0.01^{\mathrm{a}}$ & $2.12 \pm 0.01^{\mathrm{b}}$ \\
\hline
\end{tabular}

abcd represents significantly $(p=0.05)$ different means on the same column,

$\mathrm{SF}$ is sorghum flour, SBGF1 is $80 \%$ sorghum $+15 \%$ bambara nut flour $+5 \%$ date fruit flour,

SBGF3 is $80 \%$ sorghum $+20 \%$ bambara nut flour $+10 \%$ date fruit flour, SBGF5 is $60 \%$ sorghum $+25 \%$ bambara nut flour $+15 \%$ date fruit flour

Table 5: Sensory characteristics of sorghum-based breakfast cereal

\begin{tabular}{|c|c|c|c|c|}
\hline & SF & SBGF1 & SBGF3 & SBGF5 \\
\hline Colour & $5.85 \pm 1.50^{\mathrm{b}}$ & $6.50 \pm 1.30^{\mathrm{ab}}$ & $6.40 \pm 1.30^{\mathrm{b}}$ & $6.40 \pm 0.70^{\mathrm{a}}$ \\
\hline Taste & $5.00 \pm 1.50^{\mathrm{b}}$ & $5.90 \pm 1.50^{\mathrm{ab}}$ & $6.30 \pm 1.56^{\mathrm{a}}$ & $6.95 \pm 1.82^{\mathrm{a}}$ \\
\hline Aroma & $5.00 \pm 2.01^{\mathrm{b}}$ & $5.35 \pm 1.57^{\mathrm{b}}$ & $6.10 \pm 1.55^{\mathrm{ab}}$ & $6.55 \pm 1.50^{\mathrm{a}}$ \\
\hline Consistency & $5.70 \pm 1.72^{\mathrm{b}}$ & $5.95 \pm 1.50^{\mathrm{ab}}$ & $6.00 \pm 1.12^{\mathrm{b}}$ & $6.80 \pm 1.30^{\mathrm{a}}$ \\
\hline Overall acceptability & $5.30 \pm 1.63^{\mathrm{b}}$ & $6.45 \pm 1.61^{\mathrm{a}}$ & $6.25 \pm 1.21^{\mathrm{ab}}$ & $6.95 \pm 2.24^{\mathrm{a}}$ \\
\hline
\end{tabular}

ab represents significantly $(p=0.05)$ different means on the same column,

$\mathrm{SF}$ is sorghum flour, SBGF1 is $80 \%$ sorghum $+15 \%$ bambara nut flour $+5 \%$ date fruit flour,

SBGF3 is $80 \%$ sorghum $+20 \%$ bambara nut flour $+10 \%$ date fruit flour, SBGF5 is $60 \%$ sorghum $+25 \%$ bambara nut flour $+15 \%$ date fruit flour 
Finally, the overall acceptability of the blended breakfast cereal ranged between 5.30 and 6.95. The flour with $100 \%$ sorghum (SF) had the lowest overall acceptability score of 5.30 which was significantly $(p=0.05)$ different from that of SBGF1 (6.45), SBGF3 (6.25) and SBGF5 (6.95). The $60 \%$ sorghum, $25 \%$ bambara groundnut and $15 \%$ date palm composite flour (SBGF5) had the highest score of 6.95 . The gruel made from $100 \%$ had the poorest acceptance rating in terms of colour, taste, flavor, consistency and overall acceptability when compared with those made from sorghum flour with different level of substitution of bambara nut and date palm flours (SBGF1, SBGF3 and SBGF5).

\section{CONCLUSION}

The use of bambara nut and date palm fruits at various substitution level in the formulation of sorghum-based breakfast meal had a significant effect on their functional, pasting and nutritional quality. There was significant $(p=0.05)$ increase in protein, ash crude fibre and fat contents of the gruels made from the composite flours. The sensory characteristics of the sorghum-based breakfast cereal gruel were greatly affected as the gruel made with $60 \%$ sorghum flour, $25 \%$ bambara nut flour and $15 \%$ date palm fruit flour had the highest overall acceptability. The study has therefore shown that production of sorghum-based breakfast meal with substitution of bambara nut and date palm could help to improve their nutrient composition and sensory quality.

\section{REFERENCES}

Adepeju A.B., Gbadamosi S.O., Omobuwajo T.O. and Abiodun O.A. (2014). Functional and physicochemical properties of complementary diets produced from breadfruit (Artocarpus saltilis). Afr. J. Food Sci. Technol., 5 (4), 105-113. DOI: 10.14303/ajfst.2014.031

Adeyeye E. and Ayejuyo O. (1994). Chemical composition of Cola acuminata and Garcinia kola seeds grown in Nigeria. Int. J. Food Sci. Nutr., 45 (4), 223-230. DOI: 10.3109/096374894091661628

Ahmad A., Soni D., Singh K. and Marya K. (2013). Mineral profile, proximate and amino acid composition of three date varieties (Phoenix dactylifera L.). Int. J. Res., 4 (3), 417-451. DOI: 10.7897/2277-4343.04328

Akinsola A.O., Idowu M.A., Babajide J.M., Oguntona C.R. and Shittu T.A. (2018). Production and functional properties of maize-millet based complementary food blended with soybean. Afr. J. Food Sci., 12 (12), 360-366. DOI: 10.5897/AJFS2015.1387

AOAC. (2000). Official Methods of Analysis (17 th ed.), Association of Official Analytical Chemists, Gaithersburg, MD, USA, p. 925

Arogundade L., Eromosele I. and Ademuyiwa O. (2011). Rheological properties of African yam bean (Sphenostylis stenocarpa Hochst Ex A. Rich) calcium proteinate and isoelectric protein isolates. LWT Food Sci. Technol., 44, 524-534. DOI: 10/1016/j.lwt.2010.08.020
Aviara N.A., Lawal A.A., Atiku A.A. and Haque M.A. (2013). Bambara groundnut processing, storage and utilization in Northeastern Nigeria. Cont. J. Eng. Sci., 8 (1), 28-36. DOI: 10.5707/cjengsci.2013.8.1.28.36

Beuchat L.R. (1977). Functional and electrophoretic activities of peanut flour. J. Agric. Food Chem., 25 (2), 258-261. DOI: $10.1021 /$ jf60210a044

Duranti M. (2006). Grain legume proteins and nutraceutical properties. Fitoterapia, 77 (2), 67-82. DOI: $10.1016 /$ j.fitote.2005.11.008

Eneche H.E. (2006). Production and evaluation of cakes from African yam bean and wheat flour blend. Proc. $30^{\text {th }}$ Annual Conf. \& AGM Nigerian Inst. Food Sci. Technol., November 5-9, Badagry, Lagos, pp. 46-47

Enweremadu C., Waheed M. and Adeala A. (2008). The energy potential of brewers spent grains for breweries in Nigeria. J. Eng. Appl. Sci., 3 (2), 175-177

Foroogh B. (2009). Assessment of Antioxidant Potentials of Date (Phoenix dactylifera L.) Fruits. Dissertation, University of Saints, Malaysia, pp. 4-18

Govindasamy S., Campanella O. and Oates C. (1996). High moisture twin-screw extrusion of sago starch: Influence on granule morphology and structure. Carbohydrate Polymers, 30 (4), 275-286. DOI: 10.1016/S0144-8617(96)00024-0

Hillocks R., Bennett C. and Mponda O. (2012). Bambara groundnut: A review of utilization, market potential and crop improvement. Afr. Crop Sci. J., 20 (1), 1-6

Ijarotimi S. and Keshinro O. (2013). Determination of nutrient composition and protein quality of potential complementary foods formulated from the combination of fermented popcorn, African locust bean and bambara groundnut seed flour. Pol. J. Food Nutr. Sci., 63 (2), 155-166. DOI: 10.2478/v10222-012-0079-Z

Ikegwu O.J., Okechukwu P. and Ekumankana E.O. (2010). Physicochemical and pasting characteristics of flour and starch from achi (Brachystegia eurycoma) seed. J. Food Technol., 8 (2), 58-66. DOI: 10.3923/jftech.2010.58.66

Kabuo N., Dialoke S., Onuegbu N., et al. (2015). Utilization of tender pigeon pea (Cajanus cajan (L.) Mill sp.) in Nigeria. Food Sci. Qual. Manag., 35 (2015), 110-117

Kanu P., Sandy E., Kandeh B., Bahsoon J. and Huiming Z. (2009). Production and evaluation of breakfast cereal-based porridge mixed with sesame and pigeon peas for adults. Pak. J. Nutr., 8 (9), 1335-1343. DOI: 10.3923/pjn.2009.1335.1343

Lattimer J.M. and Haub M.D. (2010). Effects of dietary fiber and its components on metabolic health. Nutr., 2 (12), 1266-1289. DOI: 10.3390/nu2121266

Mbaeyi I.E. (2005). Production and Evaluation of Breakfast Cereal Using Pigeon Pea (Cajanus cajan) and Sorghum (Sorghum bicolor L.). MSc Dissertation, Department of Food Science \& Technology, Faculty of Agriculture, University of Nigeria, Nsukka, p. 166

Mbata T., Ikenebomeh M. and Ahonkhai I. (2009). Nutritional status of maize fermented meal by fortification with bambara nut. Afr. J. Food Agric. Nutr. Dev., 7 (2), 107-112

Mkandawire C.H. (2007). Review of bambara groundnut (Vigna subterranean (L.) Verdc.) production in SubSahara Africa. Agric. J., 2, 464-470

Mustafa A.I., Hamad A.M. and Alkahtani M.S. (1993). Date varieties for jam production. Proc. Symp. on the Date Palm, King Faisal University, Al-Hassa, SaudiArabia, p. 496-501 
Nnam N.M. (2001). Chemical, sensory and rheological properties of porridges from processed sorghum (Sorghum bicolor, bambara groundnut (Vigna subterranea L. Verdc) and sweet potato (Ipomoea batatas) flours. Plant Food. Human Nutr., 56 (3), 251-264

Ogundele G.F., Ojubanire B.A. and Bamidele O.P. (2015). Determination of the pasting and functional properties of cowpea (Vigna unguiculata) and soybean (Glycine max) blends. Brit. J. Appl. Sci. Technol., 6 (3), 304-309. DOI: 10.9734/BJAST/2015/11663

Ojo M.O., Ariahu C.C. and Chinma E.C. (2017). Proximate, functional and pasting properties of cassava starch and mushroom (Pleurotus pulmonarius) flour blends. Amer. J. Food Sci. Technol., 5 (1), 11-18. DOI: 10.12691/ajfst-5-1-3

Okafor G.I. and Usman G.O. (2015). Physical properties of breakfast cereals from blends of maize, African yam bean, defatted coconut cake and sorghum extract. Food Sci. Qual. Manage., 40, 25-34

Okafor G.I. and Usman G.O. (2014). Physical and functional properties of breakfast cereals from maize, African yam bean and coconut cake. Agro-Science, 13 (2), 7-6

Okoye J.I. and Obi C.D. (2017). Chemical composition and sensory properties of wheat-African yam bean composite flour cookies. Discourse J. Agric. Food Sci., 5 (2), 21-27

Okpala L., Okoli E. and Udensi E. (2013). Physicochemical and sensory properties of cookies made from blends of germinated pigeon pea, fermented sorghum, and cocoyam flours. Food Sci. Nutr., 1 (1), 8-14. DOI: $10.1002 /$ fsn 3.2
Omueti O., Otegbayo B., Jaiyeola O. and Afolabi O. (2009). Functional properties of complementary diets developed from soybean (Glycine max), groundnut (Arachis hypogea) and crayfish (Macrobrachim spp). Electronic J. Environ. Agric. Food Chem., 8 (8), 563-573

Sandhu K., Singh N. and Malhi N. (2007). Some properties of corn grains and their flours I: Physicochemical, functional and chapatti making properties of flours. Food Chem., 101 (3), 938-946. DOI: $10.1016 / j$.foodchem.2006.02.040

Sanni L.O., Kosoko S.B., Adebowale A.A. and Adeoye R.J. (2004). The influence of palm oil and chemical modification on the pasting and sensory properties of fufu flour. Int. J. Food Prop., 7 (2), 229-237. DOI: 10.1081/JFP-120026059

Small D. and Prescott J. (2005). Odor/taste integration and the perception of flavor. Exp. Brain Res., 166 (3 \& 4), 345-357. DOI: 10.1007/s00221-005-2376-9

Sodipo M., Lawal O., Alabi O., Solomon O., Oluwamukomi M. et al. (2008). Physicochemical properties and amino acid profile of extruded products from pearl millet and germinated pigeon peas. Ann. Food Sci. Technol., 19 (2), 183-190

Usman G.O., Ameh U.E., Alifa O.N. and Babatunde R.M. (2015). Proximate composition and antinutrient properties of breakfast cereal made from blends of local rice, soybeans and defatted coconut flours. J. Nutr. Food Sci., S11: S11006. DOI: 10.4172/2155-9600.1000S11006

Yuliana N., Nurdjanah S. and Dewi Y. (2018). Physicochemical properties of fermented sweet potato flour in wheat composite flour and its use in white bread. Int. Food Res. J., 25 (3), 1051-1059 